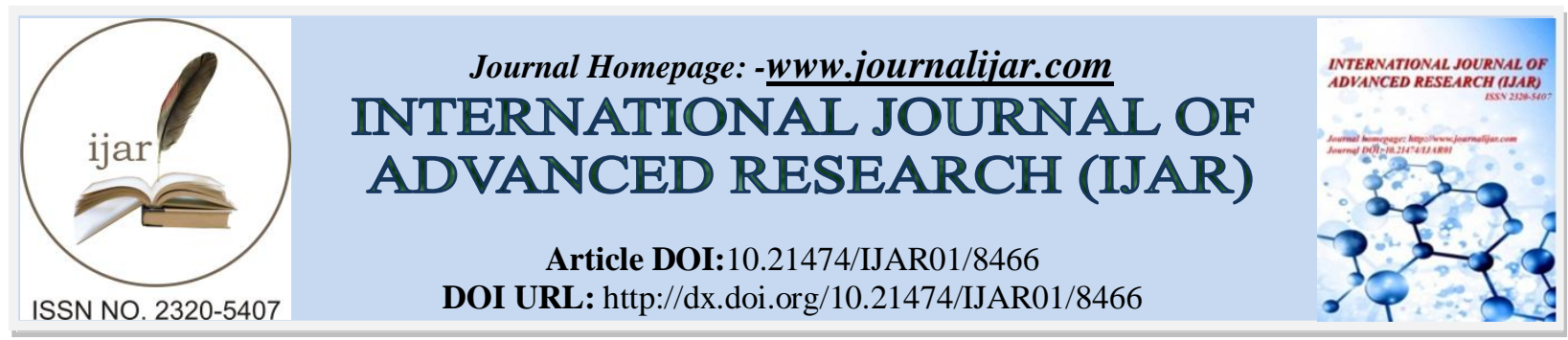

RESEARCH ARTICLE

\title{
HAEMATALOGICAL EFFECTS OF GASOLINE VAPOUR EXPOSURE BY INHALATION IN THE WISTAR ALBINO RATS.
}

\author{
Sambo N. ${ }^{1}$, D. S. Amaza ${ }^{2}$, Ojo N. $A^{3}$, Odehs.O ${ }^{4}$, Mojiminiyi, F. B. $O^{5}$ and S. Sandabe U.K ${ }^{3}$. \\ 1. Department of Human Physiology, College of Medical Sciences, University of Maiduguri. \\ 2. Department of Human Anatomy, Kaduna State University. \\ 3. Department of Veterinary Physiology, Faculty of Veterinary Medicine, University of Maiduguri. \\ 4. Department of Human Physiology, University of Jos. \\ 5. Department of Physiology, Faculty of Medicine, Usumanu DanFodio University, Sokoto.
}

\section{Manuscript Info}

Manuscript History

Received: 02 December 2018

Final Accepted: 04 January 2019

Published: February 2019

Key words:-

Gasoline, Haemoglobin, Leucocytes, Rats.

\section{Abstract}

Aims: This study is to investigate the effect of gasoline vapour exposure on haematological indices in wistar albino rats under simulated work place exposure.

Study design: Experimental study

Place and Duration of Study: College of Medical Sciences, University of Maiduguri, Borno State, Nigeria betweenFebruary September 2010.

Methodology: Adult male wistar albino rats were exposed to gasoline vapour in an exposure chamber, with concentration of gasoline vapour maintained at the lower explosive limit $1.4 \mathrm{ppm}$, daily for eight hours, five days a week for six months to simulate the normal working hours. The rats were divided into two groups, group I animals were placed $6 \mathrm{~cm}$ from the source of the gasoline vapour and group II $150 \mathrm{~cm}$ from the source.

Results: The results show a significant $(\mathrm{P}<0.05)$ increase in red blood cell count $(6.68 \pm 0.35$ and $8.03 \pm 0.27)$ and haemoglobin concentration $(11.93 \pm 0.29$ and $10.95 \pm 0.27)$. There was also a significant rise $(\mathrm{p}<0.05)$ in the total leucocyte count $(10.58 \pm 0.57$ and $9.30 \pm 0.27)$ in the exposure group I and II respectively as compared with control group (9.38 \pm 0.12$)$. Gasoline vapour exposure at work place has significant effect on haematological indices.

Conclusion: The results of this study showed that gasoline vapour exposure has effect on haematological indices, increasing the haemoglobin concentration, packed cell volume, neutrophil count, lymphocyte count, and red blood cells count.

Copy Right, IJAR, 2019,. All rights reserved.

\section{Introduction:-}

Gasoline (Premium Motor Spirit-PMS) vapour exposure is common in Nigeria, being the 12th largest producer of crude oil worldwide and the 6th largest producer in the OPEC cartel (Air Toxics Committee, 1989). Gasoline consists of hydrocarbons (aromatic, saturated and unsaturated) and on hydrocarbons $\mathrm{N}, \mathrm{S}, \mathrm{O} 2$, Vanadium and

Corresponding Author:-Sambo N.

Address:-Department of Human Physiology, College of Medical Sciences, University of Maiduguri. 
Nickel. Gasoline is volatile in nature and readily available in the atmosphere when dispensed or accidently spilled (KapilSoni, et al., 2016). The main means of exposure to gasoline is by inhalation of its vapour and direct skin contact or accidental swallowing, for example, when the mouth is used to siphon from a larger container to a smaller one. There also could be indirect exposure as in the use of contaminated water for drinking, cooking or laundry and contaminated soil as it happens in accidental spillage or sabotage (Chilcott, 2006). There are several occupations associated with respiratory diseases, e.g., those who work in gasoline filling stations, saw mills, textile industries, and flour mills (Farah et al., 2006, Mayank et al., 2007, Dhudmal et al, 2006). The artificial scarcity of gasoline and the erratic electricity supply in the country has led to the use of generators for households and industries and the storage of gasoline in containers with associated risks of spillage, leakage and even swallowing This study is to investigate the effect of gasoline vapour exposure on haematological indices in wistar albino rats under simulated work place exposure.

\section{Methodology:-}

Twenty (20) Adult Male Wistar Albino rats weighing 120-160g purchased from the animal house, Department of Clinical Pharmacology and Therapeutics of the University of Maiduguri were housed in a plastic cage with stainless steel wire lids and kept under constant laboratory conditions of 12/12 hour light/dark cycle and free access to feed and water. The animals were exposed to gasoline vapour daily for eight hours, five days a week for six months (to simulate the normal working hours). The rats were divided into two groups of ten each. The first exposure group was kept at a distance of $6 \mathrm{~cm}$ and the second exposure group at $150 \mathrm{~cm}$ from the source of the gasoline vapour in the exposure chamber. The gasoline exposure chamber is made of plywood with a tiled roof, measuring $240 \mathrm{~cm} x 120 \mathrm{~cm}$ $\mathrm{x} 90 \mathrm{~cm}$ with a sliding glass door in the front measuring $85 \mathrm{~cm} \times 60 \mathrm{~cm}$, a modification of the methods of Uboh et al., 2005 and 2008; and Al-Saggaf et al., 2009. The glass door was adequate to allow easy access and introduction of both animals and gasoline and also allows for observation during the eight hour daily exposure periods. Gasoline was purchased from an authorized filling station (Oando filling station) and introduced into the chamber in a four liter container measuring $30 \mathrm{~cm} \times 25 \mathrm{~cm} \times 9 \mathrm{~cm}$ with an opening measuring $13 \mathrm{~cm} \times 9 \mathrm{~cm}$ on its two broad sides containing $500 \mathrm{ml}$ of gasoline. Fresh gasoline was introduced on each day of exposure. The walls of the exposure chamber were not "air tight" to allow for a minimal air circulation required.

The concentration of petrol vapour in parts per million (ppm) in the chamber was thus calculated:

Gasoline conc. $(\mathrm{ppm})=$

(Kinawy, 2009)

This is to make sure that the gasoline vapour concentration is within the lower explosive limit (LEL) of 1.4ppm in order to avoid any accidental combustion/ explosion.

The results were presented as Mean \pm SEM and the student's t-test was employed using GraphPadInStat Version 3.05. Probability level of less than $5 \%(\mathrm{p}<0.05)$ was considered statistically significant.

\section{Results and Discussion:-}

The haematological analysis shows gasoline vapour has effects on the animals as shown in the following table 1.The table shows the effect of gasoline vapour exposure by inhalation relative to the distance from the source. Here there is a rise in RBC count, increase in haemoglobin concentration and PCV. It also shows increase in WBC count, particularly a rise in neutrophil and lymphocytes. There is also a relative increase in the platelet count and a significant increase $(\mathrm{p}<0.05)$ in bleeding and clotting times.

Table 1:-Effects of Gasoline Vapour Inhalation on Haematological Parameters in Albino Rats Groups $(\mathrm{n}=10)$

\begin{tabular}{|c|c|c|c|}
\hline Parameters & Control & Exposure I & Exposure II \\
\hline $\mathrm{RBC}\left(\mathrm{x} 10^{6} / \mathrm{mm}^{3}\right)$ & $5.53 \pm 0.07$ & $6.68 \pm 0.35^{*}$ & $8.03 \pm 0.27$ \\
\hline $\mathrm{Hb}(\mathrm{g} / \mathrm{dl})$ & $10.35 \pm 0.18$ & $11.93 \pm 0.29^{*}$ & $10.95 \pm 0.13$ \\
\hline $\mathrm{PCV}(\%)$ & $34.08 \pm 0.26$ & $41.58 \pm 1.20^{*}$ & $45.33 \pm 1.75$ \\
\hline Platelet $\left(\mathrm{x} 10^{3} / \mathrm{mm}^{3}\right)$ & $2.13 \pm 0.04$ & $2.34 \pm 0.05$ & $2.53 \pm 0.05$ \\
\hline WBC $\left(\mathrm{x} 10^{3} / \mathrm{mm}^{3}\right)$ & $9.38 \pm 0.12$ & $10.58 \pm 0.57 *$ & $9.30 \pm 0.27$ \\
\hline
\end{tabular}




\begin{tabular}{|c|c|c|c|}
\hline Bleeding Time & $1.63 \pm 0.09$ & $2.13 \pm 0.19 *$ & $2.58 \pm 0.14$ \\
\hline Clotting Time & $1.67 \pm 0.07$ & $1.88 \pm 0.16^{*}$ & $2.83 \pm 0.18$ \\
\hline Neutrophils (\%) & $23.83 \pm 0.29$ & $39.42 \pm 0.65^{*}$ & $40.08 \pm 1.36$ \\
\hline Eosinophils (\%) & $9.92 \pm 0.34$ & $2.17 \pm 0.42$ & $4.25 \pm 0.82$ \\
\hline Lymphocytes (\%) & $56.17 \pm 0.59$ & $48.75 \pm 0.91$ & $46.83 \pm 0.99$ \\
\hline Monocytes (\%) & $8.33 \pm 0.31$ & $7.00 \pm 0.46$ & $8.50 \pm 0.31$ \\
\hline
\end{tabular}

Gasoline vapour exposure in both experimental groups shows a significant $(\mathrm{P}<0.05)$ increase in red blood cell count (6.68 \pm 0.35 and $8.03 \pm 0.27)$ and haemoglobin concentration (11.93 \pm 0.29 and $10.95 \pm 0.27)$ for exposure group I and II respectively. This is indicative of some respiratory distress. The increase in the red cell count and haemoglobin concentration is in order to overcome the respiratory distress by increasing the oxygen carrying capacity of the blood, thus increasing oxygen delivery to the tissues and so overcoming the respiratory distress. There is a significant rise $(\mathrm{p}<0.05)$ in the total leucocyte count $(10.58 \pm 0.57$ and $9.30 \pm 0.27)$ in the exposure group I and II respectively as compared with control group $(9.38 \pm 0.12)$. The differential leucocyte count shows a significant $(\mathrm{p}<0.05)$ increase particularly in the neutrophil count $(39.42 \pm 0.65$ and $40.08 \pm 1.36)$ in exposure groups I and II as compared to the control group (23.83 \pm 0.29$)$. The increase in the per cent neutrophil count shows that the animals were exposed to stress. In all the experiments, the changes were more in exposure group I which shows that the effect of exposure to gasoline vapour is also relative to the distance of the source of vapour.

\section{Conclusion:-}

The results of this study showed that gasoline vapour exposure has effect on haematological indices, increasing the haemoglobin concentration, packed cell volume, neutrophil count, lymphocyte count, and red blood cells count.

\section{Acknowledgements:-}

The authors thank the laboratory technologist of the Human Physiology, Veterinary Anatomy, University of Maiduguri and the Chemical Pathology Laboratory of the University of Maiduguri Teaching Hospital.

\section{Competing Interests:-}

Authors have declared that no competing interests exist.

\section{Authors' Contributions}

This work was carried out in collaboration between all authors. Sambo N. was involved in conception \& design of the study and collection of data. Ojo N.A. did first manuscript writing, Sandabe U. K. managed provision of study materials and selection of subjects. Mojiminiyi F. B. O. did data analysis and interpretation and D.S. Amaza did final editing and approval of manuscript. All authors read and approved the final manuscript.

\section{Ethical Approval}

All authors hereby declare that measurement protocol have been examined and approved by the ethical committee of the University of Maiduguri, Borno State, Nigeria and have therefore been performed in accordance with the ethical standards laid down in the 1964 Declaration of Helsinki."

\section{References:-}

1. Air Toxics Committee (1989). Evaluation of the Health Effects from Exposure to Gasoline and Gasoline Vapors. Final Report Executive Summary. Northeast States for Coordinated Air Use Management (NESCAUM).

2. Al-Saggaf,S.M.,Shaker,S.,Ayoub,N.N.,Al-Jahdali,N.H., and Abdel-Hamid,G.A. (2009). Effect of Car Fuel (Gasoline) Inhalation on Trachea of Guinea Pig: Light and Scanning Microscopic Study under Laboratory Conditions. J.Anim.Vet.Adv, 8(11):2118-2124

3. Chilcott,R.P. (2006). Compendium of Chemical Hazards: Kerosene (Fuel Oil). Health Protection Agency.

4. Dudhmal, V.B., Sayeda, A., Jadhav, S.S. and Kharadkhedkar, S.S. (2006). Pulmonary Function in Saw Mill Factory Workers. Indian J PhysiolPharmacol 50(3):313-315

5. Farah,K., Sameer,S., and Tandon, O.P. (2006). Pulmonary Function in Air Conditioner Users. Indian J PhysiolPharmacol 50(1):67-72 
6. KapilSoni, Rakesh Kumar Sharma, Arun Gupta, and VedpalYadav (2016). Impact of Petroleum Fumes on Liverand Kidney Function of Petrol Filling Attendants working in South Haryana, India. European Journal of Pharmaceutical and Medical Research 3(8), 569-573

7. Kinawy, A.A. (2009). Impact of gasoline inhalation on some neurobehavioral characteristics of male rats. BMC Physiology 9(1):21 http://www.biomedcentral.com/1472-6793/9/21

8. Mayank,S., Farah, K., Siddarth, S., and Tandon, O. P. (2007).Pulmonary Functions in Petrol PumpWorkers: A Preliminary Study. Indian J PhysiolPharmacol 50(3):244-248

9. Uboh, F.E., Akpanabiatu, M.I., Eteng, M.U., Ebong, P.E., and Umoh, I.B. (2008). Toxicological Effects of Exposure to Gasoline Vapour in Male and Female Rats. The Internet Journal of Toxicology. Volume 4 Number 2

10. Uboh, F.E., Akpanabiatu, M.I., Eyong, E.U., Ebong, P.E., and Eka, O.O. (2005).Evaluation of Toxicological Implications of Inhalation Exposure to Kerosene Fumes and Petrol Fumes in Rats. ActaBiologicaSzegediensis. Volume 49 (3-4):19-22. 